\title{
Age Related Preferences of Leadership Style: Testing McGregor's Theory X and Y
}

\author{
Marjan Bojadziev \\ Provost, University American College Skopje \\ Miodraga Stefanovska - Petkovska \\ Associate Professor, University American College Skopje \\ VeneraKrliu-Handziski \\ Assistant Professor, University American College Skopje \\ Gabriela Barlakoska \\ MBA graduate, University American College Skopje
}

Received: Sep.30, $2016 \quad$ Accepted: Oct.20, $2016 \quad$ Published: October20, 2016

doi:10.5296/jmr.v8i4.10088 URL: http://dx.doi.org/10.5296/jmr.v8i4.10088

\begin{abstract}
In a today's ageing world, where companies are facing an increasing share of older employees, it has become essential to understand the preferences and potential of this emerging group of workers. The focus of this research is to identify the age related preferences of leadership using Theory X and Theory Y developed by Douglas McGregor. The results suggest that the majority of employees prefer Theory Y management style over the Theory X style. Regardless of the age of employees, evidence shows that the results were in favour of $Y$ Theory management style. In addition results capture the reflection of the preferred leadership style in relations to turnover, trust and job satisfaction of employees.
\end{abstract}

Keywords: Leadership, McGregor, age, employees 


\section{Do we need managers or leaders?}

In today's dynamic business environment, organizations, teams need effective leaders and managers groups to be able to successfully run their operations. However one of the most prominent discussion in the academic literature is the existence of differences between leaders and managers. This is reflected both in existing theories and ongoing research .Although evident similarities can be found between leadership and management such as involving influence, employees, authority and power, there are also a lot of striking differences. For example, management is usually more task-oriented and leadership is considered to be more encouraging and idealistic. Therefore many academics, researchers and others differently define the terms 'leadership' and 'management' based on identified differences between managers and leaders. Some academics argue that although management and leadership are connected; still two activities or concepts are not identical (Bass, 2010). The degree of connection is a point of disagreement (Yukl, 2010). Some common characteristics and behaviours of effective leaders are as follows: integrity, credibility, sincerity, charisma and emotional intelligence, positive energy, passion and trust. In terms of skills, those that are most important to leaders are well-organized training skills, empathic listening skills and enormous communicative skills. Amongst others, confidence, creativity, vision, inspiration, long-term focus. the sense to prioritize, strong self-esteem, willingness to share responsibility and recognition maintaining a balance between individual needs and team needs, technical or contextual expertise and more can be added to the mix.

Leadership and management involve a unique set of activities or functions. Both leadership and management involve influence, working with people, and working with effective goal management. A well balanced organization should have a mix of leaders and managers to succeed, and in fact what they really need are a few great leaders and many first-class managers (Kotterman, 2006).

The first academic that stressed this issue was Abraham Zaleznik, with his revolutionary article published in the Harvard Business Review in 1977 where he spoke about the connection between leaders and managers manifested as an appreciated contribution to an organization but at the same time as different contribution. While leaders support transformation and fresh new approaches, managers support prudent approaches through stability and less changes. Additionally, while leaders are concerned with accepting people's views and gaining their commitment, managers complete their responsibilities and primarily worry about how things will be accomplished.

Managers count value and leaders focus on creating value. Then, just as managers have subordinates and leaders have followers, managers create circles of power while leaders create circles of influence. And at last, but not final, management consists of controlling a group in order to accomplish the goals while leadership refers to the ability to influence, motivate and to empower others to contribute to organizational success. Influence and inspiration separate leaders from managers, not power and control. Gandhi inspired millions of people to fight for their rights in India's attempt to achieve independence in 1947. His vision and inspiration has been transferred from challenges into opportunities for achieving 
the dreams of many people around the world, fighting for their rights and ensuring that their mission for independence was persistent.

Warren Bennis (1989) in the On Becoming a Leader emphasizes the following differences about management as opposite to leadership:

- The manager administers; the leader innovates;

- The manager is a copy; the leader is an original;

- The manager maintains; the leader develops;

- The manager focuses on systems and structure; the leader focuses on people;

- The manager relies on control; the leader inspires trust;

- The manager has a short-range view; the leader has a long-range perspective;

- The manager asks how and when; the leader asks what and why;

- The manager has his or her eye always on the bottom line; the leader's eye is on the horizon;

- The manager imitates; the leader originates;

- The manager accepts the status quo; the leader challenges it;

- The manager is the classic good soldier; the leader is his or her own person;

- The manager does things right; the leader does the right thing

Northouse (2007) has his own view of leadership and management. According to him, an individual can be a great leader or a great manager, or both, but still they have slightly different skills and abilities. 
Table 1. Leadership vs. Management

\begin{tabular}{lr}
$\begin{array}{l}\text { Management } \\
\text { Produces Order \& Consistency }\end{array}$ & $\begin{array}{l}\text { Leadership } \\
\text { Produces Change \& Movement }\end{array}$ \\
Planning and Budgeting & Establishing Direction \\
\hline - Establishing agendas & - Creating a vision \\
- Setting timetables & - Clarifying a big picture \\
- Allocating resources & - Setting strategies \\
Organizing and Stuffing & Aligning People \\
- Providing structure & - Communicating goals \\
- Making job placements & - Seeking commitment \\
- Establishing rules and procedures & - Building teams and coalitions \\
Controlling and Problem Solving & Motivating and Inspiring \\
- Developing incentives & - Inspiring and energize \\
- Generating creative solutions & - Empowering subordinates \\
- Taking corrective action & $\bullet \quad$ Satisfying unmet needs
\end{tabular}

Source: Northouse (2007), p. 10. Adapted from A Force for Change: How Leadership Differs From Management (pp. 3-8) by J.P. Kotter, 1990, New York: Free Press.

From this presented comparison, some conclusions can be drawn. Namely, an individual can be a great leader or a great manager, or both, but a good leader is not necessarily a good manager and visa verse. A leader's vision can be transformed into action and successful implementation thanks to good management skills. Organizational success involves a combination of effective leadership and management. Also, in modern organizations, team-based organizational structures are encompassing leadership functions to work in groups and cross-department teams. Thus, there is a greater opportunity for more input from group members at all levels of the organization (Lunenburg, 1983). 
Table 2. Comparisons between Leadership and Management

\begin{tabular}{|c|c|c|}
\hline Category & Leadership & Management \\
\hline \multirow[t]{2}{*}{ Thinking Process } & Focuses on people & Focuses on things \\
\hline & Looks outward & Looks inward \\
\hline \multirow[t]{3}{*}{ Goal Setting } & Articulates a vision & Executes plans \\
\hline & Creates the future & Improves the present \\
\hline & Sees the forest & Sees the trees \\
\hline \multirow[t]{3}{*}{ Employee Relations } & Empowers & Controls \\
\hline & Colleagues & Subordinates \\
\hline & Trusts \& develops & Directs \& coordinates \\
\hline \multirow[t]{3}{*}{ Operation } & Does the right things & Does things right \\
\hline & Creates change & Manages change \\
\hline & Serves subordinates & Serves superiors \\
\hline \multirow[t]{3}{*}{ Governance } & Uses influence & Uses authority \\
\hline & Uses conflict & Avoids conflict \\
\hline & Acts decisively & Acts responsibly \\
\hline
\end{tabular}

\section{Academic perspectives on the relation between age variable and leadership}

The nexus of leadership and age is crucial in today's aging world. Due to the declining numbers of new employees and consequently older workers remaining longer, multigenerational groups will work side by side in various assignments and leadership roles (Bower and Fidler, 1994; Cufaude and Riemersma, 1999). Similarly, mixing of cross-generations resulted from increasing of compressed organizational structures where the margins that once separated "senior" from "junior "staff now are more melted (Ernst, 2000). Hannes Zacher, Kathrin Rosing, and Michael Frese in the "Leadership Quarterly", an International Journal of Political, Social and Behavioural Science published their study "Age and Leadership: The Moderating Role of Legacy Beliefs", which examined the influence of 
legacy beliefs on the relation, age and transformational, transactional, and passive-avoidant leadership behaviours. Legacy beliefs includes people's opinions about whether they will be remembered by their actions or as people. Also, it includes whether they will have a continuing influence and will leave something behind them after death. It was expected that at higher ages, low legacy beliefs obstruct transformational and transactional leadership behaviours and enhance the passive avoidant leadership behaviours. The research has been performed on 106 university professors which were between 30 and 70 years old. They provided rankings of their legacy beliefs and each professor's leadership behaviours were evaluated by one of his or her employees.

According to Hannes Zacher, Kathrin Rosing, and Michael Frese, legacy beliefs become essential for leadership behaviours as leaders mature. Precisely, they argue that high legacy beliefs represent an important mental and emotional source for leaders to maintain their effectiveness and in the same time to avoid unproductive leadership behaviour at upper ages. Furthermore, they noted that legacy beliefs gives older leaders a sense of significance and importance for their actions, while, for example, career opportunities as one of the many motivators of previous life stages become less important.

Results were in favour to general transformational leadership and its charisma (sub dimension). In addition, a plus for overall transactional leadership was given and its dynamic management-by-exception (sub dimension) but to detriment of passive-avoidant leadership.

This study emphasizes the importance of leaders' legacy beliefs for leadership behaviours. According to the authors, further examination can result in identifying additional age-related motivators that will provide the leaders with a sense of importance and purpose for their activities. For example, an important motivator for leadership in the early professional stages can be job opportunities, while generativity (McAdams \& de St. Aubin, 1992) and other pro-social motivation should become more significant when the future time at work becomes limited or this concerns the second half of life.

Another paper published by Robert I. Kabacoff from Management Research Group and Ronald W. Stoffey from Kutztown University named "Age Differences in Organizational Leadership" investigate possible age differences in organizational leadership behaviour. For this purposes, two studies were carried out. They used the same procedure.

Thus, in the first one, a diverse sample of 640 younger (25-35 years) and 640 older (45-55 years) mid-level North American department and unit managers matched for industry, job function, and gender were compared on 22 leadership behaviours and 3 effectiveness measures. Conclusion processes were assessed by using a "360-degree" strategy in which each manager has been evaluated by himself, superiors, peers, and direct reports. Each manager completed the "Self-version" of the Leadership Effectiveness Analysis (LEA), while superiors, peers, and direct reports completed the "Observer version".

The twenty-two leadership scales of the LEA are grouped into 6 functional areas: creating a vision, developing followership, implementing the vision, following through, achieving results, and team playing. 
By comparing younger and older leaders, in both leadership behaviours numerous differences have been obtained. Ratings demonstrate that older leaders in order to ensure certainty and to reduce risks are more likely to study problems, while the younger leaders with some reservations are more enthusiastic to take risks. Also, they consider the new approaches and they feel very comfortable in turbulent and changing environments.

Younger leaders were described as having more energy, intensity, and emotional expression when operating while older leaders were more likely to maintain a modest interpersonal behaviour and to be less emotionally sensitive.

The remarkable differences were noted in the area of achieving results because younger leaders were defined as more likely to search for authority, to take responsibility and control and to lead the efforts of others. Also, they energetically push achieving results with a self-confident and reasonable manner. They were also described as more likely to implement a strong orientation toward accomplishments and holding high expectations for themselves and others.

Contrariwise, concerning the team playing the older managers prevail. They were rated with higher scores on cooperation, respect to authority and empathy. This means that the older leaders demonstrate more of an active concern for other people and their needs by forming close and supportive relationships with others and they were described as loyal to their organization and respecting the opinions of others in authority.

The view of age differences resulting from this research is consistent with many of the findings obtained in past studies. The approach of younger leaders can be described as more self-focused and self-developed in the fields of career and abilities and less open to compromise because they are more open to changes and achieving results. Older leaders have a more considered approach, submerged in the traditions of the organization. Their tactic is more in the role of the good business citizen, more democratic and "other" oriented.

Yet, it is really challenging to find a way of using the unique contributions of both younger and older leaders. The companies need highly achieving individuals with an open mind who are willing to accept constant changes but at the same time, they need individuals who can help maintain the corporation's past learning through a process of mentoring. In today's companies, older and younger leaders are likely to work together in team-oriented accomplishments. A common understanding of the strengths and weaknesses of each group is essential for future success. Inversely, it is highly challenging to disregard the value of one approach and to emphasize the other because enthusiasm, innovation and modernization can easily be turned into disorder and anarchy. As well as that, conservativism can be transformed into entropy.

Similarly, Bhargava R. Kotur, S. Anbazhagan in their study "The Influence of Age and Gender on the Leadership Styles" investigates the different leadership styles of the workers and the influence of age and gender on the leadership styles of the workers in the sugar factory located at Chittoor, a south Indian town.

For the purpose of the study, three leadership styles are chosen that are at the bottom, middle 
and top of the leadership hierarchy such as autocratic, democratic and laissez-fair leadership styles. The study discloses that besides the demographic leadership style there is the dominant, age and gender which have their own influence on the workers' leadership styles or that with increasing in age, minor authority is shown by the workers. Research has been focused on 652 employees. Among them, 36 employees hold a supervisory role and the rest of them were workers. Random sampling techniques were used in the survey in order to collect the data and the sample which comprised of 127 workers out of the 616 .

The study has concluded several findings. Firstly, all the leadership styles naturally are not equally present in the employees. The democratic leadership style is more dominant between the employees then the Laissez-faire comes next and at the end, the least number of employees poses an autocratic style of leadership. This finding was similar to the conclusions of Davood Salmani and Ali Taatian (2010) based on their study on the leadership styles survey in different cultures. Secondly, several significant differences exists between male and female workers in relation to their leadership styles. To some extent the female are more autocratic than the male workers. Similar, Goleman (1995) stated that according to psychology, emotionally there are some significant differences between the male and female employees and the leadership theories have proved that emotional intelligence influences the leadership style.

Finally, the study demonstrated that the age has an extremely large influence on the leadership styles of the employees. The individuals started with more of an autocratic leadership style but through work experience they moved towards a democratic leadership style. At the later stages, they made significant changes into the laissez-faire leadership style. This is in accordance with the recognized principles of educational psychology. With growing age, knowingly or unknowingly persons obtain more knowledge and logically people tend to be more flexible and less self-confident. Therefore, they will demonstrate less authority on their colleagues. One more reason is that with growing age, persons start to substantially depend each other for some type of help. This also can distress their sensibility and it will have a significant influence on their leadership styles. This finding is also confirmed and similar with the work of Per Erik Solem (2009) on "Age Changes in Subjective Work Ability" and with the work of Belal et al., (2010) but not excluding many others.

\section{Research Instruments}

The research has been performed using the quantitative method. A questionnaire has been created which consists of 51 questions and six sections. The questions have been selected based on previous research.

It starts with 26 questions connected to $\mathrm{X} / \mathrm{Y}$ Theory of leadership. The origin of the questions is from the paper "Construct validation of a Theory $\mathrm{X} / \mathrm{Y}$ behaviour scale" from Kopelman, Protas and Falk (2009).

The next section consists of 6 questions (questions 27-32) and they are related to intrinsic motivation. The questions have been selected from the paper "Exploring the relative and combined influence of mastery-approach goals and work intrinsic motivation on employee 
turnover intention" by Kuvaas and Dysvik, 2009.

The next section consists of questions from 33 to 37 which are linked to turnover intention and they are created using the paper "An Exploration of How the Employee-Organization Relationship Affects the Linkage between Perception of Developmental Human Resource Practices and Employee Outcomes" by Kuvaas (2008).

The following section is linked to trust in an organization which consists of 3 questions (38-40) that were extracted from the paper "New work attitude measures of trust, organizational commitment and personal need non-fulfilment" by Cook and Wall (1980).

The fifth segment from 41- 3 consists of questions which were linked to satisfaction with the organization and they are from the article "Motivation through the Design of Work: Test of a Theory" by Hackman and Oldham (1975), but only 3 out of 5 questions were engaged. The last two questions were used for defining the questions above.

The final section consists of demographic data for the survey participants.

\section{Procedure for data collection \& sample selection}

The procedure was convenience sampling meaning that the questionnaires have been distributed going from responder to responder and giving them on hand. The total number of distributed questionnaires was 100 and 10 were additionally sent via e-mail.

The questionnaires circulated in the Company, allocated by different departments, starting from Monday at 10 o'clock until 15 o'clock. It took several days and the distribution finished after 5 working days.

Firstly, 30 questionnaires were distributed in the Production Department; then in Maintenance 30 more; in the Sales Department for red mix concrete 5 questionnaires; in the Sales Department of cement 15 more and in Administration 30 questionnaires. In total, 110 questioners were distributed.

The questionnaire consists of 51 questions and it is divided in six sections. The answers were designed in a five point Likert - type response format which includes: I strongly disagree; I do not agree; I don't know; I agree and I strongly agree.

The questionnaires were delivered in exposed envelopes and they were returned in sealed envelopes. Also, the employees orally were familiar with the purpose of the questionnaire. They had been informed that it was anonymous and it would be used for an educational study.

\section{Research Findings}

Analysing the answers regarding the demographic profile of the survey responders, the following can be concluded:

Graph 1 showed that participants in the survey were mostly males or $(\mathrm{N}=64) 64 \%$ and only $(\mathrm{N}=29)$ 29\% were female and the rest of $(\mathrm{N}=7) 7 \%$ did not answered this question. 
As it is presented in Graph 2, $(\mathrm{N}=35) 35 \%$ of the survey participants employees are in the age group 50 years and above and $30 \%$ are in the group $30-39$ years.
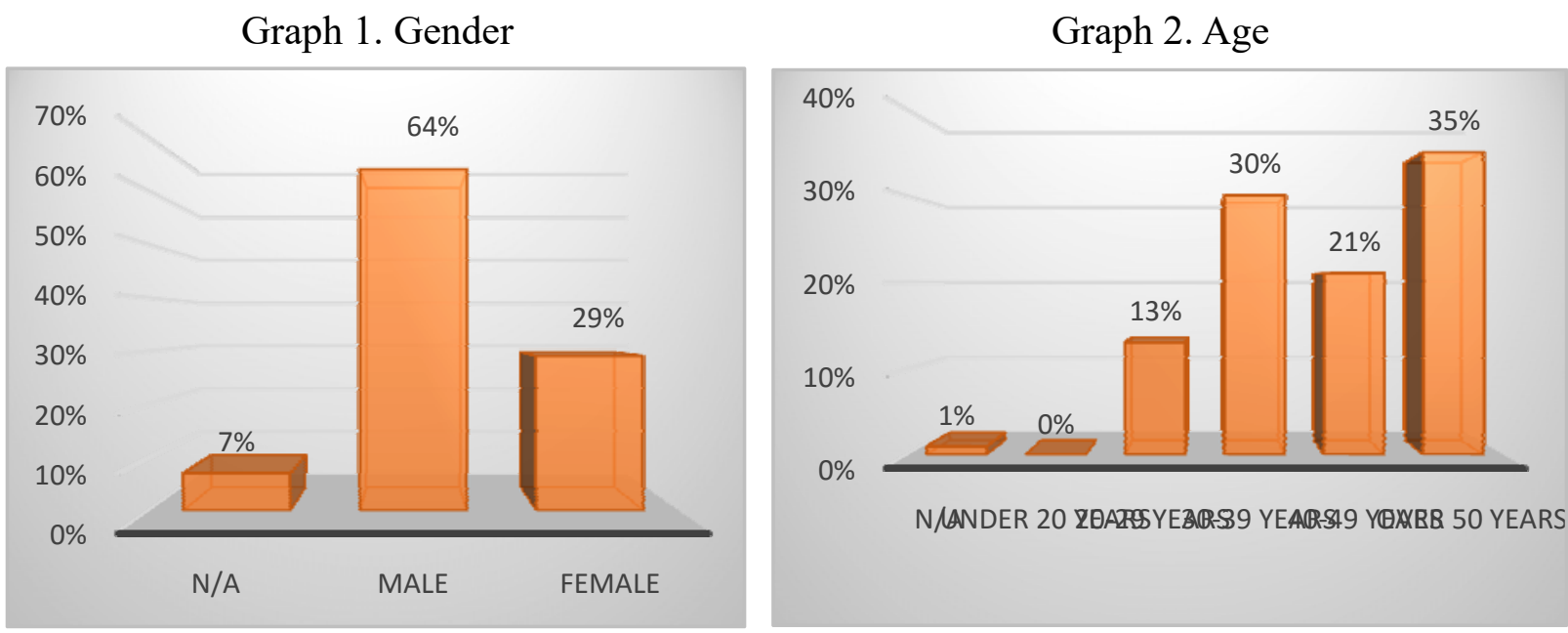

From Graph 3, it can be noted that the majority of the participants or $46 \%$ of the employees $(\mathrm{N}=46)$ finished secondary school and $42 \%(\mathrm{~N}=42)$ from the employees have finished Graduate studies (BsC).

Concerning the question about the 'Number of employees at the company', all responders $(\mathrm{N}=100)$ or $100 \%$ have answered over 250 employees.

As it is presented in Graph 4,64\% of survey participants $(\mathrm{N}=64)$ have more than 8 years of experience in the company and only $8 \%(\mathrm{~N}=8)$ are with less than a year of working experience within the company.

Graph 3. Highest education finished

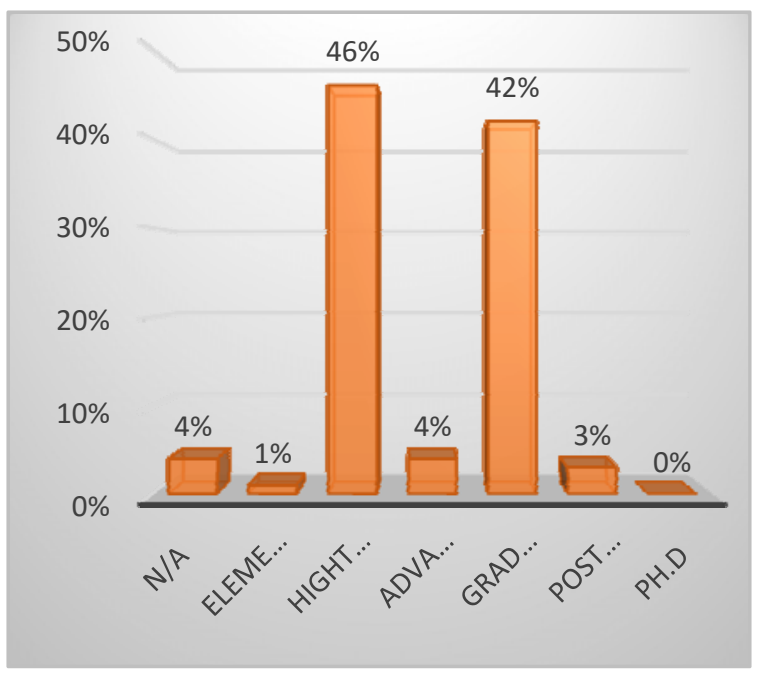

Graph 4. How long have you been employed in company

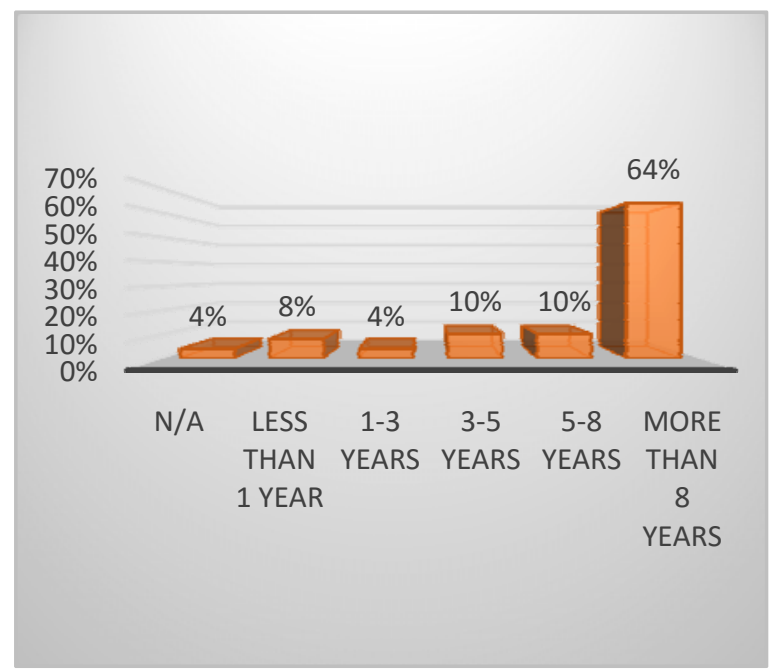

As it can be seen from the Graph $65,75 \%$ of the survey participants $(\mathrm{N}=75)$ answered that they have never been managers. 
Graph 5. Have you ever been manager

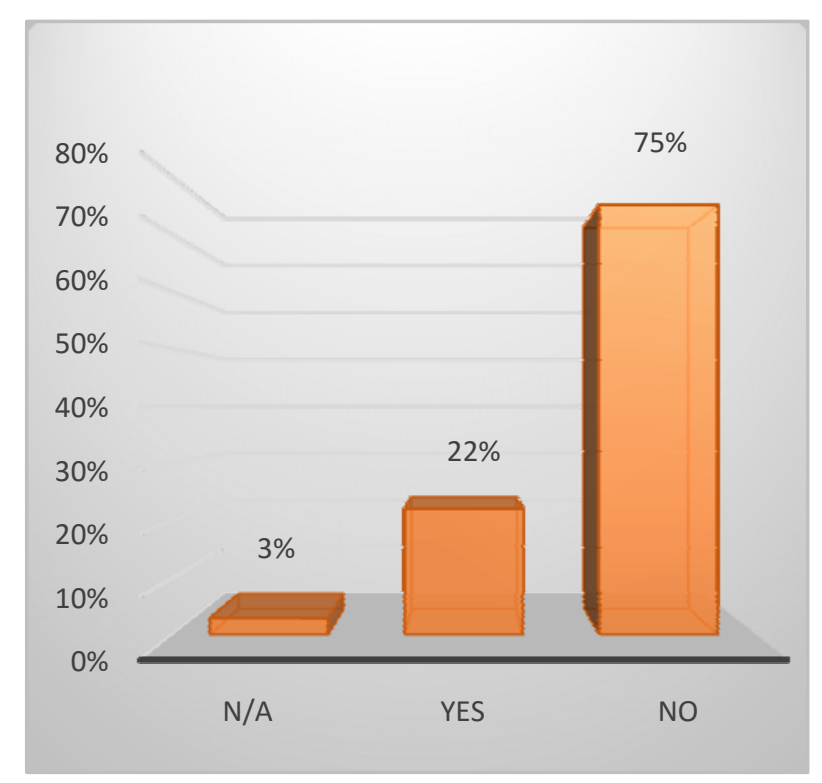

The average arithmetic value of the first section related to $\mathrm{X} / \mathrm{Y}$ Theory is 3.17 showing that the majority of the survey participants prefer managers who practise the $Y$ Theory managerial style. This is the case because they also aspire to such a way of working. Survey respondents prefer more participative management which allow employees to have space and possibility for personal development. They prefer managers who take risks, responsibility, but also who use an appropriate position structure. In general, respondents can be characterized as more positive because they believe that people are self-motivated by things that challenge them and make them strive for higher personal accomplishments.

Nevertheless, minor statements, like statement 5: "Most employees actually prefer to be told exactly what to do rather than having to figure it out for themselves", then, statement "Most people will not use their initiative or do things until they have been specifically assigned to do" and statement 24 "Most people are lazy and do not want to work" are very close to the margin of 2.5 implicating that some survey participants share the X Theory attitude. The responders who identify themselves with Theory-X can be characterized as people who have a negative view of people by saying that people are lazy; they do not have motivation; and they do not try to reach their potential. 
Graph 6. Cumulative results from other sections

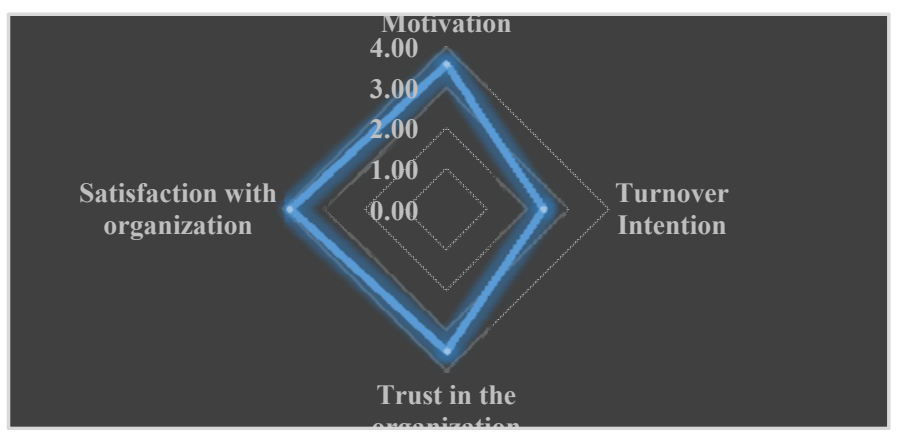

The average arithmetic values of other sections presented in the Graph 6 are: 3.57 for Intrinsic Motivation, 2.39 for Turnover Intention, and then 3.52 for Trust in the Organization and 3.84 for Satisfaction within the Organization.

The overall conclusion is that the employees in the company are quite motivated not only by the salary but other factors influence their motivation. They have exciting and meaningful jobs. Additionally, the tasks that they perform are a driving power for doing better and representa form of motivation itself. The employees have confidence in their company. They believe that the company will always make the right decisions and will implement the best solutions for the company including the employee's interests. Also, results indicate the existence of significant satisfaction within the organization in which they work, with the job they are assigned to and individually speaking they appreciate the work they have.

However, turnover intention is very near to the margin, which is 2.5 showing that there are participants who are thinking about the possibility to leave the company although that does not mean that they will quit. There are even employees who feel comfortable, secure and they see opportunity for professional growth inside the company.

Regarding age, the average arithmetic value of the first section related to X/Y Theory is 3.09 for the employees who are between 20 to 29 years; 3.19 for the employees between 30 to 39 years; 3.13 for employees who are between 40 to 49 years; and 3.20 for employees over 50 years old. The results show that although the respondents prefer the Y Theory managerial style, there is a slight difference between the oldest respondent's opinions and those who are younger. The oldest are more convinced that the managers in the company practices $\mathrm{Y}$ Theory managerial style and they seem to be their followers. 
Table 3. Summarized means for other section except section related to X/Y Theory leadership style

\begin{tabular}{|l|r|r|r|r|}
\hline \multicolumn{1}{|c|}{ Sections } & $\begin{array}{c}\text { 20-29 years } \\
\text { old }\end{array}$ & $\begin{array}{c}\text { 30-39 years } \\
\text { old }\end{array}$ & $\begin{array}{c}\text { 40-49 years } \\
\text { old }\end{array}$ & $\begin{array}{c}\text { 50 years and } \\
\text { above }\end{array}$ \\
\hline Intrinsic Motivation & 3.77 & 3.47 & 3.39 & 3.71 \\
\hline Turnover Intention & 2.60 & 2.44 & 2.50 & 2.21 \\
\hline Trust in organization & 3.46 & 3.54 & 3.21 & 3.70 \\
\hline $\begin{array}{l}\text { Satisfaction with } \\
\text { organization }\end{array}$ & 3.67 & 3.74 & 3.78 & 4.03 \\
\hline
\end{tabular}

Graph 7. Cumulative by sections $-20-29$ years old
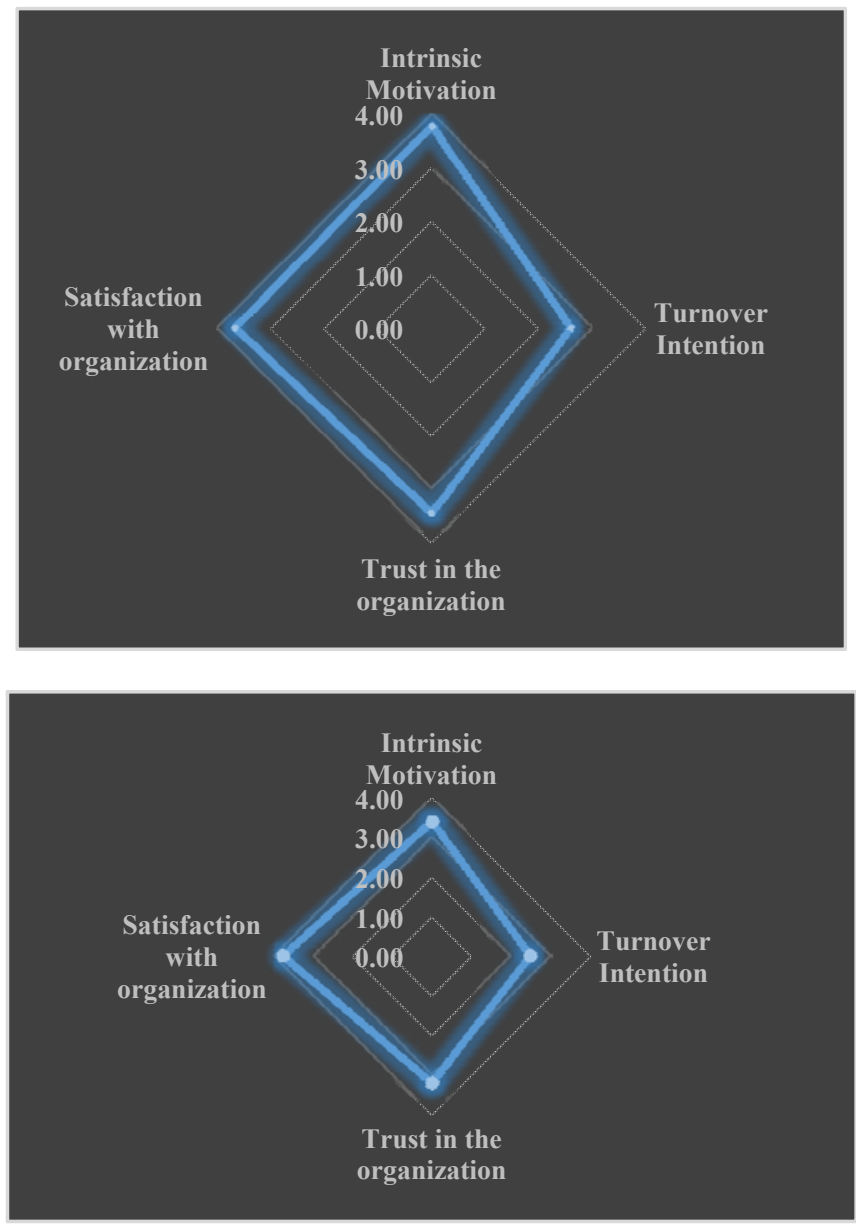

Graph 8. Cumulative by sections $-30-39$ years old
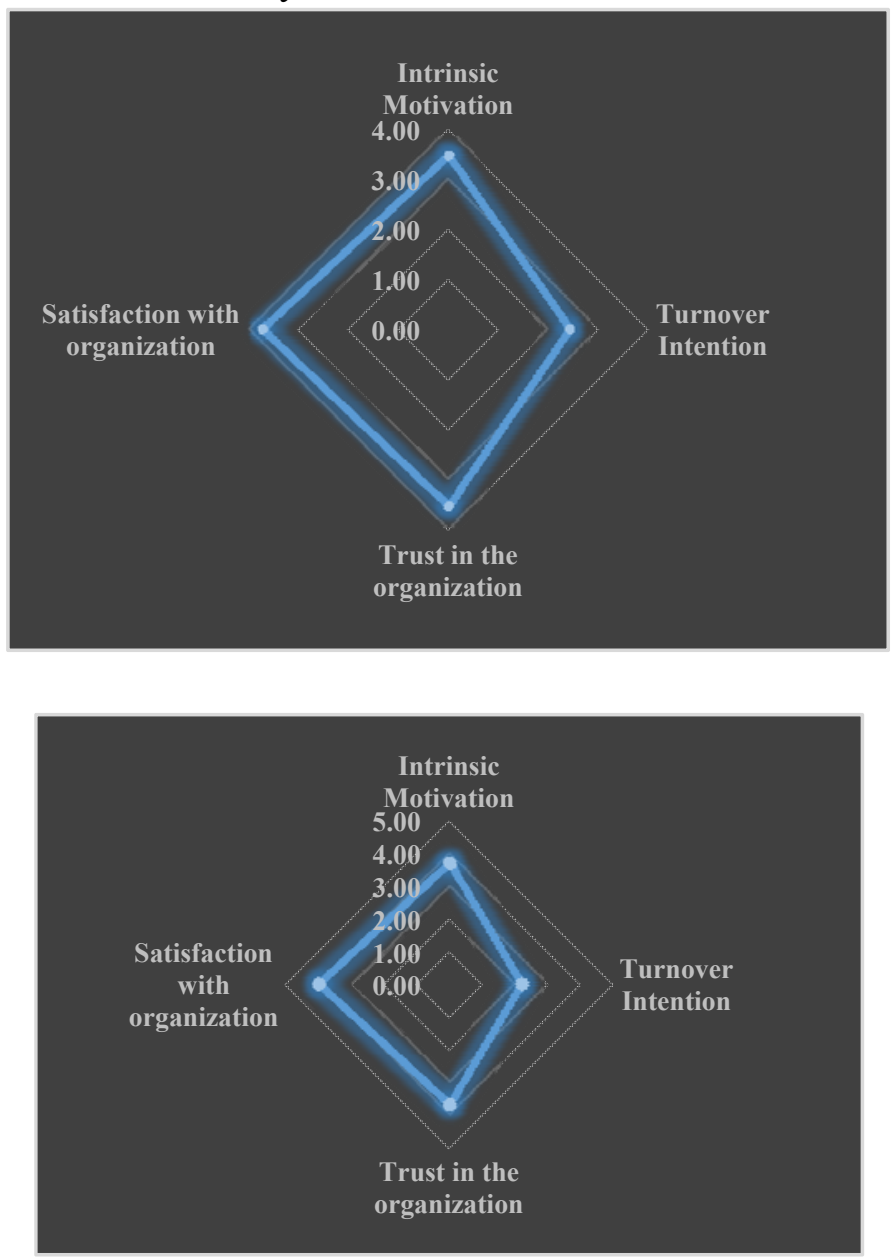

Overall, the younger and older employees share the mutual opinion that the company pays a lot of attention to the human factor within the company as a basis for performance improvement, which considers other motivation factors like education through various training and learning programs which contribute to improvement of employees' professional and personal performances on all levels and assist the development of individual skills and knowledge of employees. 
Furthermore, they all share an equal opinion about the trust and the satisfaction with the company which origin again from the healthy environment in which they work. It is manifested thorough various contributions given by the company in all areas which represent a motivation by themselves. In relation, the company is committed to the well-being of its employees and their families, thus it gives additional benefits in order to respond to their needs. The health of employees is one of the company's priorities which has been confirmed with additional efforts to extend the health prevention and protection benefits for all employees. The Company significantly appreciates and is proud of its employees, their accomplishments and their contribution to the Company's strategic goals. Also, employees' long term sustainability are awarded with jubilee awards. In an effort to create more opportunities for the employees' families, the company implements the scholarship program for the employees' children every year. Additionally, holiday celebrations for the youngest children, which receive gifts including books and other materials that further support their education, are organised on an annual level.

Nevertheless, thinking to seek other work or having ideas to leave the company is more evident for the first group (20-29 years old) and equal to the margin of 2.5 for the third group (30 - 39 year old). It shows that these two groups have some doubts and thoughts which can be transformed into an intention to leave the company. Personally, among the youngest employees, this idea is much more expressed as a result of their expectations in a very short period of time to be placed on a higher position or promoted. On the other hand, it does not mean that they are not satisfied with the company having in mind the fact that many of them did not express their opinion. It is possible for the employees aged from 40 - 49 years that we can say they are less motivated than others or feel neglected and less valuable. The company should take that into account and award incentives to further improve the managing and operating conditions but also to further improve the system of motivating employees.

\section{Discussion}

Relations between leaders and followers, managers and employees, are a very important and true benchmark for the human relations movement represented in Theories $\mathrm{X}$ and $\mathrm{Y}$ introduced by Douglas McGregor in his famous book, The Human Side of Enterprise, which was published in 1960 .

Therefore, this research has been concentrated on implications from McGregor's Theory X and Theory $\mathrm{Y}$ between employees with special attention on age variable influence. Furthermore this theory has not been studied much in our country giving it a special emphasis of importance.

This research has been conducted through a questionnaire which has been distributed to the employees within the company and the results showed the following facts.

For employees more important is security rather than opportunity for personal and professional growth. They prefer to be led by someone else and not to take initiative. Nevertheless, the majority of employees enjoy meaningful jobs and they think that they have the potential to participate in giving useful suggestions, decision making as well as in solving problems. It is confirmed that they have ambition. The majority of participants did not agree 
with the statement that it is in the human nature to dislike to work.

The average arithmetic value of the first section related to $\mathrm{X} / \mathrm{Y}$ Theory is 3.17 showing that the survey participants overall prefer managers who run through the $\mathrm{Y}$ Theory managerial style. Respondents prefer more participative management, meaning that they like managers who take risks and who use appropriate position structures that allow employees space and possibility for personal development. In general, respondents can be characterized as more positive because they believe that people are self-motivated by things that challenge them and strive for higher personal accomplishments.

Yet, a minor statements, like statement 5, "Most employees actually prefer to be told exactly what to do rather than having to figure it out for themselves", then, statement 7 "Most people will not use their initiative or do things that they have been specifically assigned to do" and statement 24 "Most people are lazy and do not want to work" are very near to the mean of 2.5 implicating that some survey participants share the $\mathrm{X}$ Theory attitude. The responders who identify themselves with Theory-X can be characterized as people who have a negative attitude towards other people by saying that people are lazy; they do not have motivation and they do not try to reach their potential.

From an age regarding perspective, the results show that even the respondents prefer Y Theory managerial style although there is a slight difference between the oldest respondent's opinions and those who are younger. The oldest are more convinced that the managers in the company practices Y Theory managerial style.

These conclusions are related to the real picture of the leadership style within USJE. It is spread into top middle and line-level leaders (managers). The managers in USJE exercise mentoring, and team leadership. The use skills such as patience, sharing information, trust, give up authority, requested interference, facilitation, trouble-shooters - problem solving, communication with others, conflict managers, coaching and others as the theory suggests (Fiedler Contingency model Fiedler / Garcia Cognitive Resource Theory, Situational leadership theory, Leader Member Exchange Theory (LMX), Path Goal Theory etc.)

By summarizing the answers from other sections in the questionnaire, the overall conclusion is that the employees in the company are quite motivated not only by the salary but other factors influence their motivation. The employees have confidence in their company. Also, results indicate the existence of significant satisfaction with the organization in which they work.

By aging differentiation, the results showed that the younger and older employees share the mutual opinion that the company pays a lot of attention to the human factor within the company as a basis for performance improvement, which considers other motivation factors. Some of them include education through various training programs and learning programs which contribute to the improvement of employees' professional and personal performances on all levels. Also, it assists the development of individual skills and knowledge of employees. They all share an equal opinion about the trust and the satisfaction with the company which origins from the healthy environment in which they work.

Nevertheless, thinking to seek other work or having ideas about leaving the company is more 
evident in the first group (20-29 years old) and equal to 2.5 of the third group (30 - 39 year old). It shows that these two groups have some doubts and thoughts which can be transformed into intention to leave the company. Frankly, among the youngest employees, this idea is much more expressed as a result of their expectations to be placed at a higher position or promoted in a very short period of time. On the other hand it does not mean that they are not satisfied with the company having in mind the fact that many of them do not expressed their opinion or maybe for the employees from 40 - 49 years we can say that they are less motivated than others or feel neglected and less valuable.

The Company should take into account this fact and reward incentives to further improve the managing and operating conditions and for further improve the system of motivating the employees.

\section{Conclusion}

The aim of the research to examine the implication from Theory $\mathrm{X}$ and $\mathrm{Y}$ between the employees in with special attention on age variable has been put in place and realized.

The main objectives were also emphasized. First of all, a critical review of academic literature theories has been provided. Especially, the importance of McGregor's Theories X and $\mathrm{Y}$ was highlighted. Namely, that it explains why so many management systems experienced downfall and at the same time it introduce the concept for a new way of managing that could not be implemented through the old organizational systems. Theory-X management was limited by factors such as money and control that can be applied. On the contrary, the opportunities for people to gain personal fulfilment, challenges, knowledge, self-awareness, respect, self-motivation and other rewards through work are really unlimited. Hence, mangers who are Theory $\mathrm{Y}$ oriented can be characterized as more positive because they believe that people are self - motivated and strive for higher personal accomplishments. The Theories $\mathrm{X}$ and $\mathrm{Y}$ surely offer chances for human resource development through team-building sessions and management development but at the same time it offers those who are at a higher position the chance to advance in self-knowledge.

Furthermore, in this study one approach has been established: the quantitative method through the questionnaire which measures $\mathrm{X} / \mathrm{Y}$ leadership style through 26 questions from the paper "Construct validation of a Theory X/Y behaviour scale" from Kopelman, Protas and Falk, 2009. Then, four section who measures Intrinsic Motivation, Turnover Intention, Trust in Organization and Satisfaction within the Organization Final section consist of demographic data for the survey participants.

The conclusion of this study shows that this measuring method (questionnaire) was well-placed and can be used as a tool for further research programs about the implications from Theory X/Y leadership.

The impressions of leadership styles, or as they seem to be by the responders, are related to employee satisfaction, their effectiveness, motivation, commitment to job and tasks, mutual trust and relationship between managers and employees. This shows that the $\mathrm{Y}$ theory of management style prevails and that contingent motivation factors different than salaries, like 
rewards and appreciation, are the most important factors in establishing high leadership style and the well-being of the employees.

Moreover, the analysis showed that trust and satisfaction within the organization is on a very high level within all generations in the Company. This is a result of a healthy environment which exists in the Company at all levels. There are rules and regulations for employees to follow. Management is concerned with high productivity but it believes that this comes through treating its people right. The Company is proud of its reputation as being a good place to work. Job activities are designed around departments and sections and around work teams. Team members are encouraged to interact with people across functions.

Results also showed that the turnover intentions seemed to have a reasonable impact on further carrier development among the youngest employees and on the middle age survey participants.

\section{References}

Batten J. D. (1989 p.35). Tough-minded Leadership. New York: AMACOM

Bass, B. (2010). The Bass handbook of leadership: Theory, research, and managerial applications. New York, NY: Simon \& Schuster.

Bennis, Warren. (1989). On Becoming a Leader. New York: Addison Wesley. Leaders, Not Managers Pp. 44-46. Warren Bennis, On Becoming a Leader: The Leadership Classic. Revised Edition.Basic Books, 2003.

Bolden, R. (July, 2004). What is leadership?(Research Report 1). Exeter, United Kingdom: Leadership South West.

Burns, J.M. (1978). Leadership. New York: Harper \& Row.

Bruce E. Winston, \& Kathleen Patterson. (2006). An Integrative Definition of Leadership. International Journal of Leadership Studies, 1(2), 6-66. School of Leadership Studies, Regent University ISSN 1554-3145.

Nahavandi, A. (2005). The Art and Science of Leadership, $4^{\text {th }}$ Ed. Upper Saddle River, NJ: Prentice Hall. ISBN-13: 978-0132544580

John Maxwell. (1998). The 21 Irrefutable Laws of Leadership: Follow Them and People Will Follow You - September 18, 1998, 11

Yukl, G. (2010). Leadership in organizations (7th ed). Upper Saddle River, NJ: Prentice Hall.

Yukl, G., \& Van Fleet, D.D. (1990).Theory and research on leadership in organizations. In M.D.

Hersey, P., \& Blanchard, K. (1988).Management of organizational behavior. Englewood Cliffs, New Jersey: Prentice Hall.

Stogdill, R.M., \& Shartle, C.L. (1948).Methods for determining patterns of leadership behaviour in relation to organization structure and objectives. Journal of Applied Psychology, 
32, 286-291.http://dx.doi.org/10.1037/h0057264

Van Vugt, M., Hogan, R., \& Kaiser, R.B. (2008). Leadership, followership, and evolution: Some lessons from the past. American Psychologist, 63, 182-196.http://dx.doi.org/10.1037/0003-066X.63.3.182

Northouse, P.G. (2010). Leadership: Theory and practice (5th ed). Thousand Oaks, CA: SAGE Publications.

Hollander, E. P. (1978). Leadership dynamics: A practical guide to effective relationships. New York: Free Press.

John W. Gardner. (1990). On Leadership: The Nature of leadership. New York: Free Press.

Casse P. (2014). The New Drivers of Leadership.[Online]. Available from: https://www.trainingjournal.com/articles/feature/new-drivers-leadership. [Accessed: 15 November 2015].

Kenneth E. Clark, \& Miriam B. Clark. (1996). Choosing to Lead. Center for creative leadership, second edition 1996-05

The Hofstede Centre. (2015). Online Available from http://geert-hofstede.com/cultural-tools.html [Accessed: November]

Hofstede, G. (1978). The poverty of management control philosophy. Academy of Management Review, 3, 50-61.

Hofstede, G. (1980). Culture's Consequences: International Differences in Work-Related Values, Sage Publications, Beverly Hills, CA.

Hofstede, G. (1983). The cultural relativity of organizational practices and theories. Journal of International Business Studies, 14, 75-89. http://dx.doi.org/10.1057/palgrave.jibs.8490867

Hofstede, G. (1998). Attitudes, values and organizational culture: disentangling the concepts. Organization Studies, 19(3), 477-92. http://dx.doi.org/10.1177/017084069801900305

Hofstede, G. (2001). Culture's Consequences: Comparing Values, Behaviours, Institutions, and Organizations Across Nations, 2nd ed., Sage Publications, Thousand Oaks, CA.

FonsTrompenaars, \& Charles Hampden-Turner. (1997). Riding the Waves of Culture: Understanding Cultural Diversity in Business (2nd ed.), London: Nicholas Brealey.

Valentin Konja, DejanMatic, \& DanijelaLalic. (2014). Social Constructionist Perspective of the Leadership in Serbia. InzinerineEkonomika-Engineering Economics, 25(4), 437-449. http://dx.doi.org/10.5755/j01.ee.25.4.3990

Kristina G. Ricketts. Community and Leadership Development. Leadership vs. Management.Cooperative Extension Service-University of Kentucky College of Agriculture, Lexington, KY 40546.

Fred C. Lunenburg. (2011). Leadership versus Management A Key Distinction - At Least in 
Theory.International Journal of Management, Business, and Administration, 14(1).

Yukl, G. (2010). Leadership in organizations ( $7^{\text {th }}$ ed.). Upper Saddle River, NJ: Prentice Hall.

Zaleznik, A. (1997). Managers and leaders: Are they different? Harvard Business Review, 55, 67-78.

Northouse, P. (2007). Leadership theory and practice. Thousand Oaks, CA: Sage Publications.

Lunenburg, F. C., Thompson, B., \& Pagani, D. (2010, May). The multifactor leadership questionnaire (MLQ): Factor structure of an operational measure. Paper presented at the annual meeting of the American Educational Research Association, Denver, CO.

Lunenburg, F. C. (1983). Conceptualizing school climate: Measures, research, and effects. Berkley, CA: McCutchan.

Northouse, P.G. (2007). Leadership: Theory and practice, 4th ed. Sage: Thousand Oaks, CA

Lunenburg, F. C. (1983). Conceptualizing school climate: Measures, research, and effects. Berkley, CA: McCutchan.

Bedeian, A.G., \& Wren, D.A. (2001). Most influential management books of the 20th century. Organizational Dynamics, 29(3), 221-225. http://dx.doi.org/10.1016/S0090-2616(01)00022-5

Miner, J.B. (2003). The rated importance, scientific validity, and practical usefulness of $\begin{array}{llll}\text { organizational behaviour 250-268. } & \text { l2(3), theories, }\end{array}$ http://dx.doi.org/10.5465/AMLE.2003.10932132

Bailyn, Berna. (1981). A quantitative review", Academy of Management Learning and Education, Vord, David Davis, David Donald, John Thomas, Robert Wiebe, and Gordon Wood. The great republic: A history of the American people. Lexington, MA: Heath.

Faulkner, Harold Underwood, \& Tyler Kepner. (1950). America: Its history and people. New York: McGraw-Hill.

Bobic P.M, \& Davis E. (2003). A Kind Word for Theory X: Or Why So Many Newfangled Management Techniques Quickly Fail. Journal of Public Administration Research and Theory, 13(3), 239-264. http://dx.doi.org/10.1093/jopart/mug022

Kopelman E.R., Prottas J.D., \&Falk W.D. (2010). Construct validation of a Theory X/Y behaviour scale. Leadership \& Organisation Development Journal, 31(2), 120-135.

Carson M. C. (2005). A historical view of Douglas McGregor's Theory Y. Management Decision, 43(3), 450-46.http://dx.doi.org/10.1093/jopart/mug022

McGregor, D. (1960). The Human Side of Enterprise. New York: McGraw-Hill Book Company.

Gabor, Andrea. (2000). The capitalist philosophers. New York: Times Business.

Bennis, Warren, Edgar H. Schein, \& Caroline McGregor. (1966). Leadership and motivation: 
Essays ofDouglas McGregor. Cambridge: The MIT Press.

Tausky, Curt. (1992). Work is desirable/loathsome: Marx v. Freud. Work and Occupation, 191, $3-18$.

Wilkinson, Adrian, Graham Godfrey, \& Mick Marchington. (1997). Bouquets, brickbats, and blinkers: Total quality management and employee involvement in practice. Organization Studies, 18(5), 799-819. http://dx.doi.org/10.1177/017084069701800505

Kirton, Michael J. (1989b). Adapters and innovators: Styles of creativity and problem solving. London: Routledge.

Kirton, Michael J. (1978). Field dependence and adaption-innovation theories. Perceptual and Motor Skills, 47(3), 1239-45.

Korth, Sharon J. (2000). Single and double-loop learning: Exploring potential influences of cognitive style. Organization Development Journal, 18(3), 87-98.http://dx.doi.org/10.2466/pms.1978.47.3f.1239

Holland, Peter A. (1987). Adapters and innovators: Application of the Kirton Adaption-Innovation Inventory to bank employees. Psychological Reports, 60(1), 263-70. http://dx.doi.org/10.2466/pr0.1987.60.1.263

McNeilly,\& Goldsmith. (1992). The moderating effect of sales managers' approach to problem solving on the salesperson satisfaction/intention to leave relationship. Journal of Social Behaviour and Personality, 7(1), 139-50.

Locke, J. (1690). Second Essay Concerning Civil Government.

Smith, A. (1776). An Inquiry into the Natural Causes of the Wealth of Nations.

Allport, G., \& Odbert, H. S. (1936). Trait-names: A psycho-lexical study. Psychological Monographs, 211. http://dx.doi.org/10.1037/h0093360

Stogdill, R. M. (1974). Handbook of leadership: theory, research, and managerial applications. New York: New York Free PRess.

Eric A. Landis, Deborah Hill, \& Maurice R. (2014). A Synthesis of Leadership Theories and Styles. Journal of Management Policy and Practice, 15(2).

Gerald Matthews, Ian J. Deary, \& Martha C. Whiteman. (2003). Personality Traits, Second Edition.U.K: Cambridge University Press. http://dx.doi.org/10.1017/CBO9780511812736

Tannenbaum, \& Schmitt.(1958). How to choose a leadership pattern.

Burns, J. M. (1978). Leadership. New York: Harper and Row.

Vector Study. (2008). Retrieved November 30, 2011, from Fiedler's Contingecy Model.

Bass, B. (1997). The Ethics of Transformational Leadership. The ethics of transformational leadership. In Kellogg Leadership Studies Project, Transformational Leadership Working Papers Transformational Leadership Working Papers, The James MacGregor Burns Academy 
of Leadership.

Borgatti, S. (2002 April). Bureaucracy. Retrieved 2011 29-November from Analytictech

Cutaja, M. (2010 July). Henri Foyol's Principles of Management. Retrieved 2011 29-November from Business Manaement@ suite 101

Bolden, R., Gosling, J., Marturano, A., \& Dennison, P. (2003). A Review of Leadership Theory and Competency Frameworks. Centre for Leadership Studies.

Avolio, B. J., \& Gibbons, T. C. (1988).Developing transformational leaders: A life span approach. In J. A. Conger \& R. N. Kanungo (Eds.), Charismatic leadership: The elusive factor in organizational effectiveness (pp. 276-308). San Francisco, CA: Jossey-Bass.

Kabacoff, R., \& Stoffey, R. (2001).Age Differences in organizational leadership. Paper presented at the $16^{\text {th }}$ Annual Convention of the Society for Industrial and Organizational Psychology, San Diego, CA

Bhargava R. Kotur, \& S. Anbazhagan. (2014). The Influence of Age and Gender on the Leadership Styles.IOSR Journal of Business and Management (JBM), 16(1), 30-36.

Bower C., \& Fidler, M (1994). The importance of generational literacy. Leadership, p.30-35.

Cufaude, J.B., \& Riemersa, M (1999).The future face of the workforce. Association Management, 51, 1-3

Ernst, C.T. (2000). Continuity through conversation: A voice for generation X. Proceeding from the 82nd Conference on Human Issues in Management, Silver Bay, New York.

McAdams, D. P., \& de St. Aubin, E. (1992).A theory of generativity and its assessment through self-report, behavioural acts, and narrative themes in autobiography. Journal of $\begin{array}{llll}\text { Personality and Social } \quad \text { Psychology, } & \text { 62(6), }\end{array}$ http://dx.doi.org/10.1037/0022-3514.62.6.1003

Goleman.D. (1995). Emotional Intelligence. New York: Bantam.

Per Erik Solem. (2009). Age Changes in Subjective Work Ability. International Journal of Ageing and Later Life. http://dx.doi.org/10.3384/ijal.1652-8670.083243

Belal A. Kaifi, \& Bahaudin G. Mujtaba. (2010). Transformational Leadership of Afghans and Americans: A Study of Culture, Age and Gender. Journal of Service Science \& Management. http://dx.doi.org/10.4236/jssm.2010.31019

Zacher, H., Rosing, K., \& Frese, M. (2011). Age and leadership: The moderating role of legacy beliefs. The Leadership Quarterly, 22(1), 43-50. http://dx.doi.org/10.1016/j.leaqua.2010.12.006 